\title{
Entre a "Construção" de Chico Buarque e a "Bauwerk" de Wira Selanski: um caso de reprodução poético-musical
}

Tito Lívio Cruz Romão*

\begin{abstract}
Ao buscar, sempre, criar, em seu próprio poema, uma densidade de som e sentido análoga à do poema de partida, o recriador procura compensar perdas que podem ocorrer na nova língua com a introdução de novos recursos ou efeitos.
\end{abstract}

MARCELO TÁPIA

\section{Introdução}

Francisco Buarque de Hollanda - ou simplesmente Chico Buarque - nasceu no Rio de Janeiro em 1944 e, ainda no início dos anos 1960, iniciou uma carreira artística que o notabilizaria como compositor, cantor e ficcionista. No campo da dramaturgia, fizeram sucesso suas peças Roda viva (1968), Calabar (1973), em parceria com Ruy Guerra, Gota d'água (1975), com Paulo Pontes e Ópera do malandro (1979). Na área de ficção, escreveu a novela Fazenda modelo (1974) e os romances Estorvo (1991), Benjamim (1995), Budapeste (2003), Leite derramado (2009), O irmão alemão (2014) e, mais recentemente, Essa gente (2019). Além de já haver recebido três vezes o Prêmio Jabuti (1992, 2004 e 2010), foi agraciado, em 2019, com o Prêmio Camões de Literatura, embora ainda não o tenha podido receber oficialmente. Não obstante, talvez seja na memória musical brasileira que Chico Buarque (doravante: $\mathrm{CB}$ ) tem sua presença mais marcante, graças à sua carreira iniciada quando ainda era bastante jovem:

* Universidade Federal do Ceará (UFC). 
No dia 5 de maio de 1965, chegou às lojas o primeiro disco de Chico Buarque de Holanda, um compacto simples da RGE que apresentava "Pedro Pedreiro" e "Sonho de um Carnaval". Na ocasião, às vésperas de completar 21 anos, Chico sonhava em cantar como João Gilberto, compor como Tom e fazer versos como Vinícius de Moraes. Relevando-se a inexperiência do estreante, pode-se afirmar que os sonhos de "Pedro Pedreiro" não estavam assim tão distantes. (SEVERIANO; MELLO, 1998, p. 89)

O sucesso no mundo das artes, que chegou relativamente cedo para $\mathrm{CB}$, pode ser explicado tanto por seu talento próprio quanto pelo ambiente em que foi criado. Filho da pianista Maria Amélia Alvim Buarque de Hollanda e do historiador Sérgio Buarque de Hollanda, nasceu e cresceu em um meio que muito the propiciava contatos com o mundo das $\operatorname{artes}^{1}$ e da intelectualidade no Brasil e também no exterior. Aos sete anos, teve a primeira experiência de vida na Itália, quando seu pai lecionou na Universidade de Roma. Anos mais tarde, autoexilou-se naquele país após a instauração do Ato Institucional no 5 pela ditadura militar brasileira.

Sobre as relações de seu filho com a literatura durante a juventude, Sérgio Buarque de Hollanda, em um depoimento escrito em 1968, mas que somente foi publicado em 1991 no jornal A Folha de São Paulo, destacou a predileção de CB por autores como Guimarães Rosa, Tolstói, Dostoiévski e Kafka. Porém, não deixou de realçar que o filho, na verdade, lia tudo o que lhe caísse nas mãos. E sobre sua arte de compor músicas e letras, o pai fez as seguintes reflexões sobre o jovem CB que então começava a despontar no cenário musical brasileiro como um dos grandes nomes que marcariam a história dos festivais e da MPB:

A música é responsável por ele ter abandonado o curso de arquitetura, decisão que tomou sozinho. O sucesso abriu uma impossibilidade de estudar. Excesso de compromissos, solicitações. Creio que, na música, ele se realiza mais, se torna muito mais feliz. É preferível um compositor

\footnotetext{
${ }^{1}$ A família Buarque de Hollanda sempre foi - e continua a ser - pródiga em artistas, pois, dos sete filhos, quatro enveredaram pelo mundo das artes: Ana, Cristina, Miúcha e CB. E a arte continua a reproduzirse também através dos casamentos: Miúcha, por exemplo, foi casada com João Gilberto, com quem teve a cantora Bebel Gilberto; Sílvia, filha de CB, é atriz, e dois dos netos do multiartista, frutos do casamento de sua filha Helena com o músico Carlinhos Brown, também se dedicaram ao mundo das artes: Chico Brown é multi-instrumentista, e sua irmã Clara Buarque já estreou nos palcos como atriz e cantora.
} 
realizado, que um arquiteto frustrado, como todo mundo sabe. Quando vai compor, geralmente fica isolado, no quarto, sozinho. A música e a letra sempre nascem juntas, uma ligada à outra, indissoluvelmente. (HOLLANDA, 1991)²

Ao longo dos anos, CB foi enveredando cada vez mais pela arte da ficção, pela literatura propriamente dita, dedicando-se a essa tarefa, mas sem abandonar a habilidade de compor letras e músicas. Prova de seu êxito como escritor ficcionista são os prêmios literários a que já fez jus. Em uma entrevista concedida à revista Nossa América, periódico do Memorial da América Latina, Humberto Werneck ${ }^{3}$ e os escritores Fernando Morais ${ }^{4}$ e Eric Nepomuceno 5 indagaram-no se, à vista de "um cuidado mais apurado, como se o autor se aproximasse da literatura com certa solenidade, como quem chega a outro patamar" (HOLLANDA, 1989), ele não estaria vivendo um processo de mudança de meio de expressão. $\mathrm{CB}$ afirmou de forma taxativa:

\begin{abstract}
Eu recuso e sempre recusei essa visão. Quando comecei a fazer música, meu caminho natural talvez fosse a literatura. Minha geração foi sequestrada pela música, que teve um impacto enorme em nós, mas nunca concordei com essa distinção hierárquica, que relega a música popular a um patamar inferior. Por outro lado, tenho consciência de que estou trabalhando com outra linguagem, que um romance não é uma letra de música. A letra acompanha a música, que vai muito pelo instinto. Um romance exige mais rigor em termos puramente literários. (HOLLANDA, 1989) ${ }^{6}$
\end{abstract}

\footnotetext{
${ }^{2}$ http://www.chicobuarque.com.br/texto/depoimentos/depoto_hollanda1.htm; acesso em 5/6/2020.

${ }^{3}$ Em 1989, Humberto Werneck lançou uma publicação em dois volumes sobre letras e músicas de CB.

${ }^{4}$ Na mesma entrevista à Nossa América, CB conta sobre Fernando Morais: “Em 1976, Fernando Morais, que tinha ido a Cuba, fez lá em casa uma projeção de slides. Naquele tempo esse negócio de vídeo não era tão difundido. Lembro até hoje da parede de casa com as imagens de Cuba. O Fernando falava da ilha, e um grupo ouvia e fazia perguntas. Para nós, tudo era novidade. Naquele tempo, só se ia a Cuba exilado ou clandestino. Fernando foi o primeiro jornalista a fazer uma viagem às claras. Depois daquela noite, veio o convite da Casa de las Américas. O grupo era formado por Ignácio de Loyola Brandão, Antonio Callado, Fernando Morais e eu. Era a primeira vez desde 1964 que brasileiros do Brasil participavam do júri: antes, só brasileiros que estavam fora, exilados. Então, as imagens projetadas na parede da minha casa foram o começo."

${ }^{5}$ Em um texto publicado no jornal O Estado de São Paulo em 1/8/1989, Eric Nepomuceno sentenciou: "Escrever é, certamente, o mais solitário dos ofícios, Chico sabe e sabia disso, pois no fundo das madrugadas nasceram quase todas as suas letras, cujas palavras costumam ser buriladas até a exaustão". ${ }^{6}$ www.chicobuarque.com.br/texto/mestre.asp?pg=entrevistas/entre_1989.htm; acesso em 5/6/2020.
} 
$\mathrm{CB}$ viveu o início da carreira em meio a um cenário político em efervescência na América Latina, onde pululavam diversos conflitos entre uma esquerda empenhada em lutar pelo Estado de Direito e uma direita dirigida por militares imbuídos em implantar regimes autoritários à base de repressão e silenciamento de diversas vozes. Na mesma entrevista, perguntado sobre uma possível influência que teria sofrido da intensa produção cultural e artística existente nos diferentes países latinoamericanos antes da ascensão de regimes militares, CB mostrou o fosso que separava os brasileiros da cultura produzida em outros países latinoamericanos. A exceção era, embora tímida, a produção musical. Sua resposta mostra como, há poucas décadas, o Brasil mantinha uma espécie de estranhamento - ou mesmo desdém - perante seus vizinhos subcontinentais. Sobre o tema, CB fez a seguinte afirmação:

Em primeiro lugar, é preciso lembrar que na minha infância e adolescência a informação circulava de maneira muito mais lenta do que circula hoje. A televisão, por exemplo, não era tão desenvolvida e poderosa. Mas a informação chegava, é claro, e era bastante. Lembro que a música latinoamericana era ouvida, e o bolero faz parte da minha memória: Agustín Lara, o trio Los Panchos, Lucho Gatica, que todo mundo achava que era mexicano e é chileno, e ainda Pérez Prado, a música cubana... Havia também a música latino-americana de Hollywood, Xavier Cugat - que é espanhol da Catalunha-, essas coisas. A música mexicana e a cubana fazem parte da minha formação, mas é bom lembrar que a gente ouvia também música francesa, música italiana, uma variedade muito maior do que a que se ouve hoje no Brasil. Do cinema mexicano, não lembro. Os ecos hispânicos vinham na música, mas a América Latina era para mim uma coisa um tanto remota. Eu não lia, por exemplo, autores do Continente: minha adolescência foi dedicada à leitura de autores brasileiros, europeus e norteamericanos. Antes do chamado boom eu praticamente desconhecia o trabalho dos escritores da América hispânica. (NOSSA AMÉRICA, 1989)

Portanto, CB contava com um extenso leque de influências que, direta ou indiretamente, recebera no campo da cultura e das artes, e que, ao longo de sua carreira, decerto lhe serviram como fontes inspiradoras. Seu talento permitiu-lhe, inclusive, escrever sobre uma cidade, Budapeste, e uma língua, o húngaro - "a única que o diabo respeita" - que não conhecia. 
Neste artigo, nossa atenção estará voltada para o texto do poemacanção "Construção" e sua tradução, em língua alemã, por Wira Selanski, tradutora - não só do alemão, mas também do ucraniano - e professora aposentada da UFRJ. Sua tradução será objeto de algumas considerações, mas também serão feitas breves incursões em outras três traduções do mesmo poema-canção para o alemão, além de alguns comentários sobre traduções existentes em espanhol, italiano e francês.

\section{Sobre a composição da "Construção" de Chico Buarque}

Muito já se escreveu sobre os versos de "Construção", poema-canção que CB lançou no ano de 1971 no elepê homônimo - e por muitos considerado o seu mais sofisticado álbum -, em que figuram, na ordem de reprodução, as seguintes canções: 1. "Deus lhe pague". 2. "Cotidiano". 3. "Desalento". 4. “Construção". 5. "Cordão". 6. "Olha Maria". 7. "Samba de Orly" ("Samba de Fiumicino"). 8. “Valsinha". 9. "Minha história" ("Gesù bambino"). 10. "Acalanto". Nesse álbum, encontra-se um CB extremamente poético, que inclusive inaugura sua parceria com o diplomata-poeta Vinícius de Moraes. "Construção" é uma composição que, por um lado, espanta por sua ousadia na escolha do vocabulário e, por outro, faz um uso - tecnicamente escolhido - de efeitos repetitivos tanto na letra da canção quanto nos acordes da melodia. O texto foi escrito em versos alexandrinos, e, no final de cada verso, há um polissílabo cuja sílaba mais forte sobe ao nível proparoxítono. Em oposição a esses requintes, o texto de "Construção" relata uma cena extraída do cotidiano de operários da construção civil. O texto contém, ainda, uma série de símiles, em sua maioria introduzidas por "como se fosse" ou ainda por "feito". Sobre o texto, Jairo Severiano e Zuza Homem de Mello (1998), pesquisadores de canções brasileiras de diversas épocas, opinaram:

[...] Esta composição tem uma melodia repetitiva, desenvolvida apenas sobre dois acordes, e uma letra extraordinária, de qualidade rara numa canção popular. É a elegia para um operário morto no exercício da profissão e narra o seu último dia, da saída de casa para o trabalho ("Beijou sua mulher como se fosse a última"), até o momento da queda fatal ("E se acabou no chão feito um pacote flácido"). Nessa letra moderna e requintada, o autor emprega ousados processos de construção poética, como por exemplo a alternância das proparoxítonas finais, "como se fossem 
as peças de um jogo num tabuleiro", segundo o próprio Chico em entrevista concedida na época: “Dançou e gargalhou como se ouvisse música / e tropeçou no céu como se fosse um bêbado / (...) / Dançou e gargalhou como se fosse o próximo / e tropeçou no céu como se ouvisse música ..." [...]. (SEVERIANO; MELLO, 1998, p. 162)

Da citação, é possível inferir que na arte de $C B$, para além das influências culturais, literárias, intelectuais e musicais recebidas, até mesmo o curso que largara na Faculdade de Arquitetura de São Paulo, em 1964, talvez lhe tenha servido como fonte de inspiração. O texto mistura arquitetura e poesia, pois revela uma complexa construção modular, como um labirinto, aliada a uma simplicidade melódica. Em entrevista concedida em 1973 à escritora Judith Patarra, CB afirmou que o texto fora construído como "experiência formal, jogo de tijolos", não tendo "nada a ver com o problema dos operários - evidente, aliás, sempre que você abre a janela" (MENESES, 2002, p. 145). Também revelou que a busca por rigor técnico numa composição desse tipo não precisa confundir-se com problemas cotidianos: “Na hora em que componho não há intenção - só emoção. Em "Construção", a emoção estava no jogo de palavras (todas proparoxítonas). Agora, se você coloca um ser humano dentro de um jogo de palavras, como se fosse... um tijolo - acaba mexendo com a emoção das pessoas". (MENESES, 2002, p. 145). No entanto, CB não podia deixar de reconhecer que, como individuo inserido numa sociedade, o compositor/poeta não vive isolado, e que isso acaba por influir diretamente em suas escolhas temáticas, pois as coisas não existem, no mesmo mundo, sem conexões mínimas entre si. Assim, CB também explica como as situações vivenciadas pelo artista, as cenas a que assiste, as pessoas com quem trava algum tipo de contato em seu dia a dia, como todas lhe servem - ainda que de modo inconsciente - de inspiração para compor suas obras poéticas, melódicas, ficcionais etc. $\mathrm{Na}$ mesma entrevista, refletiu:

Tudo é ligado. Mas há diferença entre fazer a coisa com intenção ou - no meu caso - fazer sem a preocupação do significado. Se eu vivesse numa torre de marfim, isolado, talvez saísse um jogo de palavras com algo etéreo no meio, a Patagônia, talvez, que não tem nada a ver com nada. Em resumo, eu não colocaria na letra um ser humano. Mas eu não vivo isolado. Gosto 


\begin{abstract}
de entrar no botequim, jogar sinuca, ouvir conversa de rua, ir a futebol. Tudo entra na cabeça em tumulto e sai em silêncio. Porém, resultado de uma vivência não solitária, que contrabalança o jogo mental e garante o pé no chão. A vivência dá a carga oposta à solidão, e vem da solidariedade - é o conteúdo social. Mas trata-se de uma coisa intuitiva, não intencional: faz parte da minha formação que compreende - igual aos outros de minha geração - jogar bola e brigar na rua, ler histórias em quadrinhos, colar, aos seis anos, cartazes a favor do Brigadeiro, por causa dos meus pais, contrários ao Estado Novo. (MENESES, 2002, p. 145)
\end{abstract}

Já que "tudo é ligado", pode-se supor que, de forma intencional ou apenas intuitiva, a tessitura de "Construção" conta uma cena que o artista pode/deve ter vivenciado ou pelo menos imaginado. Unindo versos alexandrinos a um vocabulário matematicamente escolhido com proparoxítonas no fim de cada um de seus quarenta e um versos, as quais passam por uma alternância semântica como se fosse uma troca de tijolos, CB apresenta o último dia da vida de um operário que parecia trabalhar como um autômato. Como trabalhador obediente, cumpria com seu dever de erguer paredes sólidas como se fosse mágico. Aquele operário, ao que parece, não podia exigir muito da vida, e aproveitava algum minuto de descanso como se fosse um dia livre, e os breves momentos de alegria, desfrutava-os como algo especial. O feijão com arroz a que a canção alude, uma refeição comum entre muitos operários brasileiros, aponta para a vida simples do personagem, sem quaisquer luxos. A história ali contada, com intenção ou não de busca por um significado social, ou apenas como obediência aos ditames da "emoção" do poeta, coloca o leitor do poema ou o ouvinte da canção perante uma história que conecta a construção poética com a concreta construção de um prédio. É um imbricamento de sonho poético e realidade crua. Se, por um lado, um operário sobe a um alto patamar da construção e de lá despenca de modo fatal, também as palavras finais de cada verso alçam um voo proparoxítono para, em seguida, despencarem em queda vertiginosa como "um pacote flácido". A pouca importância que se costuma dar à morte de uma pessoa simples, sem meios para sobreviver, fica registrada nos versos em que o homem "morreu atrapalhando o tráfego / o público / o sábado". 
Para se proceder à análise de uma tradução - ou adaptação, recriação, transcriação etc. -, é necessário, antes, reconhecer o produto da escrita poética de partida, que segue as regras de funcionamento de uma língua e de uma cultura específicas. Mas antes de abordarmos algumas questões relativas à tradução, destacamos, a seguir, algumas considerações feitas pelo jornalista José Nêumanne sobre "Construção":

\begin{abstract}
Poetas da superfície chorarão sobre a sofisticação rítmica necessária para escandir os vocábulos que Camões burilou. Não Chico, poeta afeito ao ar rarefeito dos píncaros. Ele vai além e explora a riqueza semântica da composição de versos com polissílabos, radicalizando a dificuldade rítmica com o uso de vocábulos proparoxítonos. A letra de Construção chama atenção exatamente pela proliferação das rimas internas (talvez fosse o caso de defini-las como íntimas) nas últimas palavras dos versos. Uma contradição em termos? E também um achado primoroso. Afinal, ela não cumpriria sua intenção de narrar - e denunciar, sem discursar, mas apenas relatando - o acidente de trabalho como um quebra-cabeças, se seu autor não tivesse tanta habilidade para explorar as nuances rítmicas que só os proparoxítonos peculiares às flores do Lácio permitem. (NÊUMANNE, 1999, s.p.)
\end{abstract}

Nêumanne ressalta o recurso de $\mathrm{CB}$ aos polissílabos proparoxítonos, artifício que, para "poetas da superfície", notadamente se o poema se destinasse ao canto, não teriam escolhido, já que podem representar um entrave à manutenção do ritmo e da cadência no texto poético. Mas CB resolvera construir um poema de quarenta e um versos, nos quais há, em cada um deles, “(...) exatamente doze sílabas poéticas, cuja acentuação rítmica recai sobre a sexta e a décima segunda sílaba dos versos, tornandoos, portanto, alexandrinos perfeitos" (MAGALHÃES, 2011, p. 1808). Para Macambira (1983, 103), o verso alexandrino, "nativo da França, onde predomina como verso da epopeia e da tragédia" e propagado para outros países, notadamente Alemanha, Espanha e Inglaterra, é definido desta maneira: 
O alexandrino é um verso dodecassílabo, que acentuado na sexta e na décima-segunda sílabas, se biparte em dois hexassílabos - dois versos formados de seis sílabas cada um:

a) Ó formosos sertões, ubérrimos e claros; 19, p. 25677)

b) E me lembra, gemente, o lar abandonado; 19, p. 257)

Bipartíveis um e outro em dois hexassílabos completos:
a) Ó formosos sertões,
b) ubérrimos e claros!

Cada hexassílabo se chama hemistíquio (do gego hemi "meio" stíchos "verso"), por conseguinte, meio verso. Esta etimologia esclarece parcialmente a estrutura do alexandrino clássico. (MACAMBIRA, 1983, p. 103-104)

Para aproximarmos a noção de versos alexandrinos um pouco mais da realidade de uma canção brasileira, que é o principal objeto de estudo neste artigo, recorremos aqui às palavras de Marcela Ulhôa Borges Magalhães (2011), segundo quem o dodecassílabo não é, originariamente, um "verso de tradição portuguesa". Sua percepção por alguém que tenha o português como língua materna é facilitada por uma razão simples, como afirma a pesquisadora:

\begin{abstract}
Como o dodecassílabo não é um verso de tradição portuguesa, o ouvinte, na verdade, percebe ritmicamente dois versos de seis sílabas poéticas, que, além de soarem mais naturalmente na prosódia do português, também se adequam mais propriamente à canção popular. Esses versos, unidos na manifestação textual, assim como tijolos em uma construção, constituem os alexandrinos que arquitetam toda a construção do poema. (MAGALHÃES, 2011, p. 1808)
\end{abstract}

\footnotetext{
${ }^{7}$ Os números indicados por Macambira (1983) após cada verso referem-se à citação de um poema do escritor cearense Antônio Sales (1868-1940).
} 
Com base nas explanações de Macambira (1983) e Magalhães (2011), podemos afirmar que, ao compor sua "Construção" com versos alexandrinos, CB recorreu a uma estrutura de versos que não é uma forma natural da nossa prosódia; todavia, por tratar-se de um modelo poético bipartido, seus dois hexassílabos prestam-se ao ritmo melódico de nossos ouvidos de falantes do português. Segundo esse raciocínio, tomando o verso alexandrino "Amou daquela vez como se fosse a última", temos a possibilidade de desmembrá-lo em dois hexassílabos, sem que ocorram quaisquer prejuízos à estrutura rítmica do poema: "Amou daquela vez / Como se fosse a última". Tomemos como exemplo uma canção popular de origem portuguesa como "Ciranda, Cirandinha" ("Ciranda cirandinha / Vamos todos cirandar ( Vamos dar a meia volta / Volta e meia vamos dar"); ou ilustremos, ainda, com uma canção de origem estrangeira - mas definitivamente assimilada em nossa cultura -, a tão conhecida Parabéns pra você ("Parabéns pra você / Nesta data querida / Muitas felicidades / Muitos anos de vida"), composta originalmente nos Estados Unidos no final do século XIX. Reconhecemos, no ritmo das duas canções, a prosódia mais natural aos ouvidos do nosso povo. Assim, embora cause impacto com seus longos versos dodecassílabos, o texto "Construção" não soa estranho a ouvintes brasileiros.

Ivo Braak (1980, p. 105) explica que “alexandrino é a abreviação de verso alexandrino, assim chamado porque foi primeiramente usado após meados do século XII em poemas épicos do ciclo de lendas em torno de Alexandre, o Grande (Epopeia de Alexandre, o Grande; antes de 1180) [...]"8. Braak (1980) apresenta como exemplo um verso do poema barroco Abend (1663), da autoria do alemão Andreas Gryphius, que fez largo uso de versos alexandrinos em seus sonetos: “Der schnelle Tag ist hin / Die Nacht schwingt ihre Fahn" ${ }^{9 \prime}$. Braak também destaca os esforços de poetas alemães do século XVII, como Martin Opitz, e do século XVIII, como Johann Christoph Gottsched, em adotar o alexandrino na criação poética alemã, uma tentativa

\footnotetext{
${ }^{8}$ Minha tradução deste trecho: "Alexandriner ist gekürzter Ausdruck für alexandrinischer Vers, so benannt, weil er zuerst nach Mitte des 12. Jhs. in altfrz. erzählenden Gedichten aus dem Sagenkreis um Alexander d. Gr. („Alexanderepos”; vor 1180) angewendet wurde”.

${ }^{9}$ Em tradução livre: "Foi-se rápido o dia / A noite agita seu manto".
} 
novamente feita no século XIX, por exemplo, por Friedrich Rückert, em seu poema "Die Weisheit des Brahmanen" [A sabedoria do brâmane].

Feitas essas considerações, apresentaremos, a seguir, o texto completo de "Construção" e sua tradução em alemão, feita por Wira Selanski, bem como uma retrotradução, em português, da versão alemã. Em seguida, discorreremos brevemente sobre essa tradução, apoiando-nos em algumas concepções de tradução poética.

\section{Sobre a "Construção" de Chico Buarque e a "Bauwerk" de Wira Selanski}

A principal palavra-chave presente na composição de CB ora analisada é seu título: o termo "construção" remete, por exemplo, concretamente ao canteiro de obras, ao prédio que está sendo erguido ou ao prédio já erguido, mas também, em um contexto mais restrito e, de certo modo, mais abstrato, no dizer de Houaiss \& Villar (2001), à “ação de compor, elaborar (algo), dandolhe uma estrutura; composição, elaboração, criação $<c$. de um romance $><c$. de uma personagem $>$ ", ou ainda, também segundo Houaiss, "distribuição e encadeamento de vocábulos em fases, orações, períodos, segundo o sentido e conforme as regras de cada idioma $<c$. de uma frase na voz passiva $>$ ". A língua alemã, na qual Wira Selanski (doravante: WS) compôs a versão aqui abordada, é conhecida por sua "precisão" e por, aparentemente, admitir menos polissemias que a língua portuguesa. Dessa forma, uma rápida consulta a um dicionário alemão-português dá-nos uma lista de opções de termos correspondentes, cada um com um determinado significado, ao termo "construção" = Bau, Baustelle, Baubranche, Erstellung, Bauindustrie, Konstruktion, Bauwirtschaft, Anlage, Aufstellung ${ }^{10}$.

Embora nosso foco de atenção aqui esteja voltado especificamente para a reconstrução poética realizada por WS, também recorreremos, quando necessário, a três outras traduções da mesma letra de $\mathrm{CH}$ já publicadas: a) Baustelle, tradução de Heiner Faber (FABER, 1987); b) Hochhausbau, tradução de Ingrid Schwamborn (SCHWAMBORN; SPERBER, 1990); e c) Das Bauwerk, tradução de Sarita Brandt (BRANDT, 1992). Para a palavra-título, os quatro tradutores optaram por uma palavra composta em

\footnotetext{
${ }^{10}$ https://browse.dict.cc/portugiesisch-deutsch/constru\%C3\%A7\%C3\%A3o.html; acesso: 5/6/2020.
} 
alemão. A composição por justaposição é uma característica desse idioma e abre espaço para um vasto leque de criações. Duas das soluções encontradas para o título são termos com sentidos bastante concretos em alemão: Baustelle corresponde a "canteiro de obras", e Hochhausbau significa "construção de um prédio". Já a palavra "Bauwerk" também contém, em princípio, a ideia de uma construção erguida pela mão humana; mas, por outro lado, também denota uma obra monumental ou de maior importância. Esse termo é fruto da justaposição de dois substantivos: Bau = "construção" e Werk = "obra". A palavra Werk, de conteúdo polissêmico em alemão, também abre espaço, associada à história contada no texto, para a ideia de um "produto do trabalho criativo".

Quanto à composição das outras três traduções alemãs mencionadas, diferentemente da reprodução poética realizada por WS, nenhuma delas apresenta-se como um poema em versos alexandrinos. Vejamos, a seguir, o texto completo de CB e a recriação de WS:

\author{
"Construção" \\ (Chico Buarque de Hollanda)
}

Amou daquela vez como se fosse a última Beijou sua mulher como se fosse a última E cada filho se como se fosse o único

E atravessou a rua com seu passo tímido Subiu a construção como se fosse máquina Ergueu no patamar quatro paredes sólidas Tijolo com tijolo num desenho mágico Seus olhos embotados de cimento e lágrima Sentou pra descansar como se fosse sábado Comeu feijão com arroz como se fosse um príncipe Bebeu e soluçou como se fosse um náufrago Dançou e gargalhou como se ouvisse música E tropeçou no céu como se fosse um bêbado E flutuou no ar como se fosse um pássaro E se acabou no chão feito um pacote flácido Agonizou no meio do passeio público Morreu na contramão atrapalhando o tráfego

Amou daquela vez como se fosse o último Beijou sua mulher como se fosse a única

E cada filho seu como se fosse o pródigo

E atravessou a rua com seu passo bêbado

Subiu a construção como se fosse sólido
Bauwerk (Wira Selanski ${ }^{11}$ )

Er liebte diesmal so als wäre es auf Nimmermehr Er küsste seine Frau als ob sie eine Letzte wär Umarmte jedes Kind als wäre es sein Einziges Durchquerte die Allee mit seinem schüchtern zagen Schritt Er stieg den Bau hinauf wie üblich ganz maschinenhaft Und hob ins Blau hinauf vier neue Wände riesenstark Von Stein auf Stein gefügt ein zauberhaftes Meisterwerk Er sah es mit dem Blick halb staubblind und halb tränenblind Er setzte sich nun hin als wäre es schon Feiertag Verzehrte wie ein Prinz sein täglich karges Mittagsmahl Er trank und schluchzte auf als wäre er ein Bettelmann Und lachend tanzte dann als hört er nahe Musiker Verlor sein Gleichgewicht als wäre er ein Betrunkener Und schwebte in der Luft als wäre es ein Vogelflug Und prallte auf den Grund wie ein Paket so erdenschwer Starb auf der Gegenspur auf einem regen Boulevard Und hinderte damit den regelrechten Stadtverkehr

Er liebte diesmal so als ob er Allerletzter wär Er küsste seine Frau als wäre sie die Einzige Umarmte jedes Kind als wär es ein Verlorenes Durchquerte die Allee als wäre er ein Betrunkener Er stieg den Bau hinauf als wär er selber riesenstark

${ }^{11} \mathrm{http} / / /$ sites.utoronto.ca/elul/Wowk-Wira/Wira-Wowk_Choven-na-obriju_Spohady.pdf; $\quad$ acesso em 5/6/2020. 
Ergueu no patamar quatro paredes mágicas Tijolo com tijolo num desenho lógico Seus olhos embotados de cimento e tráfego Sentou pra descansar como se fosse um príncipe Comeu feijão com arroz como se fosse o máximo

Bebeu e soluçou como se fosse máquina

Dançou e gargalhou como se fosse o próximo

E tropeçou no céu como se ouvisse música E flutuou no ar como se fosse sábado

E se acabou no chão feito um pacote tímido

Agonizou no meio do passeio náufrago

Morreu na contramão atrapalhando o público

Amou daquela vez como se fosse máquina

Beijou sua mulher como se fosse lógico

Ergueu no patamar quatro paredes flácidas

Sentou pra descansar como se fosse um pássaro

E flutuou no ar como se fosse um príncipe

E se acabou no chão feito um pacote bêbado

Morreu na contramão atrapalhando o sábado
Und hob ins Blau hinauf vier neuer Wände Meisterbau Von Stein auf Stein gefügt ein ungeheures Zauberwerk Er sah es mit dem Blick halb stadtblind und halb mörtelblind Er setzte sich nun hin gleich einem wahren Märchenprinz Und aß sein karges Mahl als wäre es ein Henkerschmaus Er trank und schluchzte auf durchaus maschinenhaft Und lachend tanzte dann mit seinem schüchtern zagen Schritt Er stolperte im Blau als hört er nahe Musiker

Und schwebte in der Luft als wäre es schon Feiertag Und prallte auf den Grund wie ein Paket auf Nimmermehr Und endete alsdann als wäre er ein Bettelmann

Und hinderte damit den öffentlichen Stadtverkehr

Er liebte diesmal so wie üblich ganz maschinenhaft Und küsste seine Frau als wäre sie schon tränenblind Und hob ins Blau hinauf vier hohe Wände erdenschwer Und setzte sich zur Ruh als wäre er dann vogelfrei Und schwebte in der Luft als täte es ein Märchenprinz Und prallte auf den Grund wie ein Betrunkener Starb auf der Gegenspur und hinderte den Feiertag

Para esclarecer o sentido assumido pelo texto de CB na recriação de WS, apresentaremos, a seguir, uma retrotradução ${ }^{12}$ literal em português do texto "Bauwerk", livre de métrica e rimas. Isso será útil para não-falantes do alemão, que poderão intuir que conteúdos foram preservados na versão alemã.

\section{Construção ${ }^{13}$}

Amou daquela vez como se fosse para jamais

Beijou sua mulher como se fosse a última

Abraçou cada filho seu como se fosse o único

Atravessou a avenida com seu passo hesitante e tímido

Subiu a construção como sempre feito máquina

E ergueu rumo ao azul quatro novas paredes hercúleas

Composta de tijolo sobre tijolo uma obra-prima mágica

Olhou-a com a vista meio ofuscada pela poeira e pelas lágrimas

Sentou-se agora como se já fosse feriado

Consumiu seu parco almoço diário como um príncipe

Bebeu e soluçou como se fosse um mendigo

E então dançou rindo como se ouvisse músicos próximos

Perdeu o equilíbrio como se fosse um bêbado

E flutuou no ar como se fosse o voo de um pássaro

E esbarrou no chão como um pacote bem indolente

Morreu na contramão numa avenida movimentada

E assim atrapalhou o tráfego urbano regular

\footnotetext{
${ }^{12}$ Feita pelo autor deste artigo para fins meramente didáticos.

${ }^{13}$ Nossa retrotradução.
} 
Amou daquela vez como se fosse o último

Beijou sua mulher como se fosse a única Abraçou cada filho seu como se fosse um pródigo

Atravessou a rua como se fosse um bêbado

Subiu a construção como se ele mesmo fosse hercúleo

E ergueu rumo ao azul uma obra-mestra de quatro novas paredes

Composta de tijolo sobre tijolo uma tremenda obra-mágica

Olhou-a com a vista meio ofuscada pela cidade e pela argamassa

E sentou-se agora como um verdadeiro príncipe encantado

E comeu sua parca refeição como se fosse a última

Bebeu e soluçou totalmente como máquina

E rindo dançou com seu passo tímido e hesitante

Tropeçou no azul como se ouvisse músicos próximos

E flutuou no ar como se já fosse feriado

E esbarrou no chão como um pacote para jamais

E então acabou como se fosse um mendigo

E assim atrapalhou o tráfego urbano público

Amou daquela vez como sempre totalmente qual máquina

E beijou sua mulher como se já estivesse cega pelas lágrimas

E construiu no azul quatro altas paredes indolentes

E sentou-se para descansar como se então fosse livre igual a um pássaro

E flutuou no ar como se o fizesse igual a um príncipe encantado

E esbarrou no chão como um bêbado

Morreu na contramão atrapalhando o feriado

\section{Sobre a tradutora}

Antes de abordarmos a análise da tradução feita por WS, apresentaremos alguns dados sobre sua vida, para melhor entendermos seu trabalho de recriação poética. Wira Selanski ${ }^{14}$, poeta, romancista, contista, ensaísta, tradutora e professora, porta-voz da literatura ucraniana no Brasil e na América do Sul, nasceu na Ucrânia. Aprendeu diferentes idiomas nesta sequência cronológica: ucraniano, polonês, alemão, inglês, português e francês. Frequentou a escola primária ainda na Ucrânia, mas numa escola polonesa, pois o oeste do país estava sob o domínio polonês. Quanto aos estudos secundários, WS cursou um ano num ginásio ucraniano, mas foi obrigada a fugir para a Alemanha devido à invasão comunista, tendo concluído a escola secundária em Dresden. No mesmo país, cursou

\footnotetext{
${ }^{14}$ Em alguns livros, o nome da autora e tradutora aparece como Wira Selanski, em outros, como Wira Wowk.
} 
Germanística, Eslavística e Musicologia na Universidade de Tübingen, entre os anos de 1945 e 1949. Em 1949, emigrou para o Brasil, onde, em 1952, doutorou-se na Pontifícia Universidade Católica do Rio de Janeiro, tendo defendido a tese intitulada Deutsche epische Mariendichtung im Mittelalter (em tradução livre: Poesia épica de louvar Maria na Idade Média). Entre os anos de 1952 e 1986, foi professora na Universidade Santa Úrsula; entre 1986 e 1996, lecionou na UFRJ e na Faculdade de Letras em Cabo Frio (Literatura Comparada e Poética). WS tem uma produção autoral com cerca de oitenta títulos, além de muitas traduções do ucraniano e do alemão para o português. Na área de Literatura de Expressão Alemã, merecem destaque, por exemplo, estes seus livros adotados por professores brasileiros nos cursos de Germanística: Renovos de Mitos (SELANSKI, 1986); Fonte. Correntes da Literatura Alemã (SELANSKI, 1997); As poesias de "Niedere Minne" de Walther von der Vogelweide (SELANSKI, 1997); Fonte. A Balada Alemã (SELANSKI, 1998); e Fonte. Antologia da Lírica Alemã (1999). Nessas obras, discorre sobre os temas e apresenta poemas originais em alemão e as respectivas traduções - realizadas por ela - em português.

\section{Alguns aspectos da análise da tradução}

Sabemos que as palavras não-monossílabas da língua portuguesa, no tocante às sílabas tônicas, operam de três maneiras possíveis, aqui apresentadas num crescendo: oxítonas ou agudas (com acento tônico na última sílaba: maré, cantar, amor etc.), paroxítonas ou graves (com acento tônico na penúltima sílaba: carro, porto, pele etc.) e proparoxítonas ou esdrúxulas (com acento tônico na antepenúltima: solícito, fúnebre, âmago etc.). Outras línguas, como o italiano e o espanhol, também admitem um quarto e até um quinto nível de acento tônico: são as chamadas palavras superproparoxítonas ou, em espanhol, sobresdrújulas (ex.: explíquemela, cómpratelo) ou, em italiano, bisdrucciole, com acento tônica na quarta última sílaba (ex: assottìgliameli, ricòrdatela) e até mesmo, em italiano, trisdrucciole, com acento tônico na quinta última sílaba (ex.: telèfonaglielo, òccupatene). Já o francês apresenta uma preponderância de palavras oxítonas (ex.: parler, jadis, gâteau, madame, régime, pertinence ${ }^{15}$ etc.),

\footnotetext{
${ }^{15}$ Ressalte-se que o "e" no final dos três últimos vocábulos é mudo.
} 
contando com um número reduzido de paroxítonas potenciais, que por vezes são reduzidas à condição de oxítonas (ex.: désirable, souffle, filiforme, risible, sobre, poularde etc.). Diante do exposto, é lícito supor que, em línguas como o italiano e o espanhol, seja plausível a recriação poética da "Construção" de CB, conservando-se, inclusive, a intenção - ou o resultado do labor poético amparado em emoções e intuições - de fazer constar, no final de cada verso, uma palavra proparoxítona.

Em 1978, a cantora italiana Ornella Vanoni gravou, no LP Uomo mio, bambino mio, uma versão italiana da "Construção" de CB que fora realizada por Sergio Bardotti. Tomemos os seis primeiros versos da versão italiana à guisa de exemplo:

\author{
Amò tutta la notte come fosse l'ultima \\ Baciò la donna sua come se fosse l'ultima \\ Ed ogni figlio suo come se fosse l'único \\ E attraversò la strada col suo passo timido \\ Salì la costruzione come fosse macchina
}

Alzò sul ballatoio due pareti solide

\begin{abstract}
Visando a alcançar o mesmo efeito de poesia a ser cantada na mesma melodia, na mesma cadência e no mesmo ritmo da canção brasileira, o tradutor Sergio Bardotti precisou recriar o poema-canção de CB conservando o aparato estrutural básico da composição: os versos alexandrinos e a presença das proparoxítonas no final de cada verso. O tradutor também contou a "mesma" história do poema original, com vistas a manter o vínculo temático principal com o poema de CB. Imaginamos que a língua espanhola também se prestaria facilmente a esse jogo de recriação poética, tanto pela proximidade semântica quanto pela existência de palavras proparoxítonas em seu vocabulário. Não se pode decretar impossível uma versão francesa do poema-canção de $\mathrm{CB}$, mas podemos supor a perda causada pela inexistência de proparoxítonas, sobretudo se o escopo da versão francesa for que o poema seja cantado no mesmo ritmo e na mesma cadência que a canção brasileira.
\end{abstract}


Quanto às sílabas tônicas, a língua alemã diverge dos outros idiomas acima mencionados, justamente por entender a acentuação silábica de forma diferente. Sobre a acentuação na língua alemã, é importante observar:

\begin{abstract}
Na língua alemã não há acentos gráficos; estes só se encontram em certas palavras estrangeiras usadas com mais ou menos frequência. Ex. Café, café; Coupé, compartimento. A sílaba tônica nas palavras que constituem a língua alemã é, geralmente, a sílaba do radical. Ex.: Besuch, visita; Gesellschaft, sociedade. Nos compostos por justaposição de duas ou mais palavras a sílaba tônica é a sílaba do radical do primeiro elemento. Ex.: Haustür, porta da casa; Schulzimmer, sala de aula. (PIRES, 1997, p. 11-12)
\end{abstract}

Como já foi dito, a língua alemã é pródiga em compor vocábulos por justaposição. Ao serem pronunciados, os compostos têm uma sílaba tônica, mas, a depender de sua extensão, também há sílabas subtônicas, por exemplo: Grundstück, Grundstückspreis, Grundstückspreis-Index, Grundstücksverkehrsgenehmigungszuständigkeitsübertragungsverordnung. ${ }^{16}$

Graças a essa propriedade, em alemão, uma palavra composta poderá ser um trunfo na composição de poemas. Ademais, como recurso específico de sua prosódia, a língua alemã pode atribuir ênfase a um determinado vocábulo dentro da frase, seja para realçá-lo, seja porque esta é a ênfase normal dentro de uma dada frase. Com base em alguns exemplos extraídos do poema "Bauwerk", observamos, em primeiro lugar, que WS, ao recontar a história do poema de $\mathrm{CB}$, recriou em alemão versos alexandrinos que sempre terminam com uma palavra ou um sintagma que, de uma forma ou de outra, preenchem a função de proparoxítonas. Algumas vezes, a proparoxítona não existe numa única palavra, mas é fruto da combinação de palavras que se encontram ligadas em um sintagma que combina, por exemplo, substantivo e verbo: "Er liebte diesmal so als wäre es auf Nimmermehr / Er küsste seine Frau als ob sie eine Letzte wär / Umarmte jedes Kind als wäre es sein Einziges / Durchquerte die Allee mit seinem schüchtern zagen Schritt". O trissílabo composto "Nimmermehr" pode ser reconhecido como palavra proparoxítona (sílaba mais forte: "Nim-", assim

\footnotetext{
${ }^{16}$ Cf. Romão, 2018.
} 
como a palavra "Einziges" (sílaba mais forte "Ein-"). No segundo verso citado acima, o dissílabo "Letzte" recebe uma ênfase diante dos outros vocábulos da frase ("eine", "wäre" etc.), criando, dessa forma, um sintagma em que praticamente há uma espécie de proparoxítona, assumindo-se a leitura de "Letzte wär" como um único bloco. Esse recurso vai se repetir também no verso "Er liebte diesmal so als ob er Allerletzter wär", onde o sucedâneo da proparoxítona se encontra no sintagma "Allerletzter wär" (sílaba mais forte: "letz-").

No tocante às palavras compostas a que WS recorre, há casos bastante ilustrativos em que se cria a proparoxítona necessária, normalmente mediante derivação afixal ou composição por justaposição, a fim de que o ritmo melódico e a cadência da canção de CB também se repitam em alemão: maschinenhaft (mecânico, maquinal, automático); riesenstark (tremendamente forte, hercúleo), Meisterwerk (obra-prima), tränenblind (cego pelas lágrimas), Feiertag (dia festivo, feriado), Mittagsmahl (almoço), Bettelmann (mendigo), Musiker (músicos), Betrunkener (bêbado), Vogelflug (voo de pássaro), erdenschwer (pesado como terra, indolente), Stadtverkehr (trânsito urbano), Einzige (única), Verlorenes (perdido), Meisterbau (construção de mestre, construção magistral), Zauberwerk (obra mágica), mörtelblind (cego pela argamassa), Märchenprinz (príncipe de contos de fadas), Henkerschmaus (última refeição [de um condenado]), vogelfrei (livre como um pássaro).

Ainda sobre alguns dos vocábulos compostos utilizados por WS, apoiando-se na palavra-título "Bauwerk", destacamos que a tradutora recorreu, em sua versão, a duas palavras que contêm o vocábulo Werk: Meisterwerk (obra-prima) e Zauberwerk (magia, "obra mágica"). Na retrotradução em português, mantivemos o sintagma "obra mágica", evidenciando a insistência de WS no termo "obra". Isso também ocorre com "Meister", que já surge em Meisterwerk e retorna em Meisterbau ("obramestra"), um vocábulo não dicionarizado, mas possível de ser construído e compreendido.

Em praticamente todos os exemplos acima WS conseguiu reproduzir, de maneira natural, uma cadência proparoxítona, à exceção da palavra Boulevard, que, como atesta o dicionário de pronúncia alemã Duden - Das 
Aussprachewörterbuch (MANGOLD, 2005), também em alemão é pronunciada como uma oxítona. Cremos, todavia, que a tradutora tenha recorrido a uma licença poética. A tradutora também recorre à licença poética ao escrever "(...) gleich einem wahren Märchenprinz", pois, conforme a correção gramatical, deveria ser "(...) gleich einem wahren Märchenprinzen".

Sobre uma concepção de tradução aplicável à análise da recriação poética intitulada "Bauwerk", de WS, a partir da "Construção", de CB, fazemos usos das seguintes palavras de Marcelo Tápia no prefácio que escreveu à 5a edição do livro Poetas de França, em que são apresentados poemas originais franceses e as traduções de Guilherme de Almeida (TÁPIA, s.d.):

\begin{abstract}
Por entender a tradução de um poema como uma nova produção artística, Guilherme - após rejeitar o verbo "traduzir", cuja definição considerou inadequada ao caso da poesia -, propõe, para essa ação, o conceito de "reproduzir", ou "re"-"produzir" (a fim de explicitar a etimologia da palavra), isto é, "produzir de novo". Ainda que a composição do poema em português parta de outro em francês, ela proporcionará um poema análogo a este, também independente, ou seja, não será um texto à sombra de outro, ou subordinado a ele. Ao conceber a tradução poética como "re-produção", Guilherme enfatiza a produção, isto é, a criação. Aliás, o poeta foi introdutor, entre nós, de diversos outros termos para melhor designar a tradução de poesia, entre eles o hoje tão utilizado "recriação" - que dimensiona, portanto, a atividade tradutória como criação -, "transcrição" $(\text { sic })^{17}$ e "transfusão", que viria a ser seu preferido. (TÁPIA, s.d., p. 5).
\end{abstract}

Essas ideias apresentadas por Tápia, que nos conduzem até Guilherme de Almeida e sua concepção do tradutor de poesia como um "reprodutor" de poesia, podem ser aplicadas ao contexto da tradução de WS. Ao nos debruçarmos sobre o texto de WS, fazendo uma leitura e em seguida uma tentativa de inclusive cantar sua "Bauwerk", obedecendo ao ritmo e à cadência da melodia criada por $C B$, damo-nos conta de que, de maneira geral, isso é possível, graças à reprodução dos versos alexandrinos e dos vocábulos ou sintagmas proparoxítonos presentes no final de cada um dos

\footnotetext{
${ }^{17}$ Entendemos tratar-se de "transcriação", palavra que, por um lapso, foi escrita como "transcrição".
} 
versos. Temos de admitir, é verdade, que uns poucos versos apresentam uma certa complexidade prosódica, talvez pelo encontro de sílabas foneticamente complexas, o que se reflete negativamente sobre a harmonia da cadência. Para ilustrar, apresentamos estes dois versos: "Durchquerte die Allee mit seinem schüchtern zagen Schritt" e "Er sah es mit dem Blick halb stadtblind und halb mörtelblind". O primeiro verso contém palavras que, por sua natureza fonética, quebram ou dificultam a harmonia necessária à cadência do verso, a saber: durchquerte e schüchtern. O mesmo ocorre, no verso seguinte, com os vocábulos halb stadtblind e halb mörtelblind.

No que tange às frequentes símiles encontradas na "Construção" de $\mathrm{CB}$, percebemos que WS tentou reproduzir em sua "Bauwerk", sempre que possível, todas elas, recorrendo a diversas possibilidades na língua alemã: a) "so als wäre es auf Nimmermehr"; b) "als ob sie eine Letzte wär"; c) "als hört er nahe Musiker"; d) "ganz maschinenhaft"; e) "wie ein Packet"; f) "so wie üblich ganz maschinenhaft" etc. Entendemos que essas soluções foram aplicadas com a garantia de que igualmente se pudessem manter a métrica e o tema da história narrada no poema. Há de se ressaltar que WS utiliza, duas vezes, a palavra "Packet", quando a grafia correta é "Paket".

Outra peculiaridade do poema-canção de CB são as alternâncias semânticas empreendidas pelo autor, ao realizar a sofisticada troca das palavras-tijolos nas paredes do texto. WS logra reproduzir o modelo de CB, sempre tentando fazer um equilíbrio entre o metro e o sentido das palavras. Como são duas línguas bastante distintas, é imprescindível que algumas mudanças, durante a reprodução poética, ocorram. Nos exemplos abaixo, vemos a alternância das proparoxítonas no final de cada verso, cotejando os versos de CB com os de WS:

a) Comeu feijão com arroz como se fosse um príncipe Verzehrte wie ein Prinz sein täglich karges Mittagsmahl

b) Comeu feijão com arroz como se fosse o máximo Und aß sein karges Mahl als wäre es ein Henkerschmaus 
WS viu-se obrigada a operar, já no primeiro verso, uma rearrumação das palavras dentro do verso reproduzido em alemão, sem que isso, contudo, gerasse uma grande diferença de sentido em relação ao poema original. Fazendo uma tradução literal do primeiro verso, teríamos em português: "Comeu como um príncipe sua parca refeição do meio-dia". Também traduzido mot à mot, o segundo verso teria este sentido: “E comeu sua parca refeição como se fosse a última". Vemos, nesse procedimento, o cuidado de WS em manter o sentido do texto original, apoderando-se, porém, sobretudo da intenção estrutural que muito bem percebeu na obra de partida. Embora tenha feito algumas mudanças nos versos, conseguiu empreender a alternância semântica no final de cada verso. Os exemplos a seguir revelam a mesma técnica tradutória:

a) Morreu na contramão atrapalhando o tráfego Und hinderte damit den regelrechten Stadtverkehr

b) Morreu na contramão atrapalhando o público Und hinderte damit den öffentlichen Stadtverkehr

c) Morreu na contramão atrapalhando o sábado Starb auf der Gegenspur und hinderte den Feiertag

Apresentando uma tradução literal em português dos três versos reproduzidos por WS em alemão, temos: a) "E assim atrapalhou o tráfego urbano regular"; b) "E assim atrapalhou o trânsito urbano público"; e c) "Morreu na contramão atrapalhando o feriado". Percebemos uma estratégia similar à explicitada acima, pois WS tenta - e logra - manter o sentido das palavras do original, mas sem reproduzi-las literalmente na mesma ordem de sua aparição, tentando, com isso, também cumprir sua tarefa de salvar a riqueza estrutural do poema original. Assim, para "tráfego", usa o termo "Stadtverkehr", uma palavra composta por justaposição ("Stadt" = cidade e "Verkehr" = trânsito, que, juntos, dão a ideia de trânsito urbano). No segundo verso, como talvez desejasse, de igual maneira, preservar a ideia da palavra 
"público", não conseguiu usar o correspondente alemão ao substantivo "público" (Publikum, Öffentlichkeit, Zuschauer etc.). Talvez isso tenha-se devido à necessidade de manter, simultaneamente, a métrica, o sentido das palavras e a alternância semântica. Não obstante, ainda recorreu à ideia de "público" (öffentlich) como epíteto de "Stadtverkehr" (tráfego, trânsito). Há, no novo texto, um certo deslocamento de sentido, pois agora o transtorno não é causado ao público em geral, mas ao trânsito/tráfego público, ou seja, aos que por ali trafegavam. Esse sutil deslocamento mostra a estratégia encontrada por WS para resolver um dos muitos impasses que uma reprodução poética dessa natureza certamente pode implicar. Por fim, no terceiro verso, a alternância foi realizada com "Feiertag" (feriado, dia festivo). Supomos que, ao buscar uma tradução para "sábado", a escolha de WS não recaiu sobre o correspondente direto em alemão ("Samstag") por questões, também desta vez, de cunho meramente estrutural, pois, com essa palavra, contaria com uma sílaba a menos.

Com relação à escolha de alguns outros termos, sobretudo os que se inserem na esfera da cultura brasileira, entendemos que os motivos tenham sido outros. Quando CB afirma que o operário "comeu feijão com arroz", sabemos tratar-se, aqui, de uma comida bastante simples, pois sequer estava acompanhada de carne, frango, peixe etc. Tendo como pano de fundo as culturas dos países germanófonos, fazer uma tradução literal, como ocorre nas outras três outras traduções alemãs mencionadas (aß Reis und Bohnen/aß Bohnen und Reis), não faria muito sentido para leitores que, se não conhecessem certos hábitos alimentares brasileiros, não captariam por completo o sentido dessas palavras. Em vez de buscar a denominação de um prato comumente encontrado no cotidiano de pessoas simples do mundo germanófono para ajustá-lo ao poema, WS preferiu afirmar "Verzehrte wie ein Prinz sein täglich karges Mittagsmahl” (tradução literal: "Consumiu seu parco almoço diário como um príncipe"). Dessa maneira, aquele operário simples não mais é apenas brasileiro: pode ser de qualquer lugar do mundo.

Chama também a atenção a troca do sentido de "náufrago" por "Bettelmann" (mendigo), nos seguintes versos: 
a) Bebeu e soluçou como se fosse um náufrago Er trank und schluchzte auf als wäre er ein Bettelmann

b) Agonizou no meio do passeio náufrago Und endete alsdann als wäre er ein Bettelmann

Cremos que WS tenha escolhido "Bettelmann" (mendigo) para reproduzir a ideia de "náufrago", porque seu correspondente literal em alemão, "Schiffbrüchiger" ou "Gestrandeter", que aparecem nas outras traduções, talvez lhe tenham causado certas dificuldades quanto à manutenção da harmonia com outras palavras dos versos, já que ambos os vocábulos alemães são longos e têm, de certa forma, uma pronúncia um tanto mais difícil de acompanhar o ritmo e a cadência do poema-canção.

Ao nos determos sobre um cotejo textual com a ajuda da retrotradução, saltam aos olhos algumas metáforas criadas pela tradutora. Para indicar a altura que assume o prédio em construção, WS faz uso do substantivo Blau (azul), que facilmente pode ser entendido como "céu", "firmamento", como uma indicação da altura que o edifício vai assumindo. Por outro lado, para indicar a ideia de "última refeição", usa um idiomatismo alemão: Henkerschmaus [trad. lit.: festim do carrasco], sinônimo de Henkersmahlzeit [refeição do carrasco], que antigamente significava a última refeição de um condenado à morte; metaforizada, a expressão assume a ideia de última refeição, por exemplo, antes de uma separação.

\section{Considerações finais}

De modo geral, a reprodução poética - e musical - da "Construção" de CB por WS em forma de sua "Bauwerk" é louvável pela ousadia da tradutora em tentar - e na maioria das vezes realmente lográ-lo - dizer a mesma coisa ou, a bem da verdade, no dizer de Umberto Eco (2013), “dire quasi la stessa $\operatorname{cosa}^{18 \prime}$, em sua versão alemã. E WS conseguiu fazê-lo, sem descurar, ademais, da sofisticada forma e estrutura desenhada por $\mathrm{CB}$, que abrange

\footnotetext{
18 "Dizer quase a mesma coisa".
} 
métrica com versos alexandrinos e a repetição de palavras de forma alternada dentro do texto.

Ao referir-se à existência de duas antologias de poemas traduzidos sob duas perspectivas distintas por dois conhecidos poetas brasileiros Manuel Bandeira e Augusto de Campos -, Ana Cristina César (2016) lança as seguintes perguntas:

\begin{abstract}
O que é que essas duas práticas diversas de tradução (que implicam em uma escolha constante: quem, o que e como traduzir) revelam a respeito de uma atitude geral relacionada com os problemas da tradução de poesia? $\mathrm{O}$ que pensam esses dois tradutores sobre o ato de traduzir? Mais ainda: sobre a tradução de determinados textos num contexto social definido? (CÉSAR, 2016, p. 450)
\end{abstract}

Lendo as explanações feitas por César, com a ajuda dessas perguntas, sobre as ações tradutórias dos dois poetas-tradutores mencionados, logo nos fica claro que, ao contrário de Bandeira, Campos produziu uma antologia bilíngue; além disso, o leitor defronta-se, afirma César (2016, p. 450-451), "com um livro de poesias de Manuel Bandeira, cuja autoria é compartilhada com 57 poetas" (2016, p. 451). Nesse livro, não há notas nem prefácio nem referências; o "autor é remetido diretamente às traduções". César também explica que, por ser uma antologia com tantos escritores cujos poemas foram vertidos, todos, pelo mesmo tradutor para o português, "o efeito imediato é o desaparecimento das diferenças entre os autores" (CÉSAR, 2016, p. 450451). César ainda relata o fato de o soneto Unrealities, de e. e. cummings, ter sido "desmodernizado" por Bandeira, que acabou transformando-o num "poema romântico, iniciando-se cada verso com letras maiúsculas, com a pontuação 'corrigida', os adjetivos suavizados e um vocabulário mais rebuscado, mais afinado com a tradição poética romântica" (CÉSAR, 2016, p. 452). Ao abordar o trabalho de Augusto de Campos, a autora destaca certos "estandartes" ou "lemas radicais" pelos quais poetas lutaram e a que Campos dará preferência: a) irreverência temática; b) "tecnologia" poética ou artesanato formal rigoroso; c) significado intencionalmente "obscuro" ou "difícil"; e d) um tipo de poesia mais intelectual, em oposição à de tipo emocional (CÉSAR, 2016, p. 455-463). 
Apoiando-nos nessas duas visões de tradutores expostos por César (2016), assumimos que a reprodução/recriação poética de WS apenas traz um único exemplo de poema traduzido; não dispomos, portanto, de uma antologia poética com obras de diversos autores representantes de diferentes estilos. Entretanto, podemos reconhecer na tradução de WS que ela, de certa forma, operou com uma "irreverência temática", primeiramente pinçada por $\mathrm{CB}$, sobretudo se levarmos em consideração a época - com uma forte ditadura militar vigente no Brasil - em que "Construção" foi lançada. O poema-canção, escrito para ser cantado, também dispunha de uma "tecnologia poética e um artesanato formal rigoroso", que WS, sem deixar de obedecer à irreverência temática ali posta, soube incorporar em sua reprodução poética. Seguindo a leitura de César (2016), cabe a ilação de que, no caso específico da tradução de "Construção", WS efetuou um trabalho de tradução na linha seguida por Campos. Salientemos, ainda, as tentativas da tradutora em criar o mesmo ambiente prosódico com a introdução de palavras e/ou sintagmas em busca de imitar as proparoxítonas no final de cada verso.

Não podemos destacar, necessariamente, um significado intencionalmente "obscuro"19 ou "difícil" - o tema é por demais cotidiano , mas aquela poesia é, antes de tudo, de tipo "intelectual em oposição à de tipo emocional". Fazemos essa afirmação, embora ainda possam ecoar as palavras de $\mathrm{CB}$, citadas mais acima: "na hora em que componho não há intenção - só emoção". WS soube igualmente reconhecer e reproduzir essa natureza intelectual do poema, coincidindo, em seu trabalho prático, com as palavras citadas na epígrafe deste artigo. WS buscou e alcançou, em larga escala, a meta de criar, no novo poema em alemão, uma "densidade de som análoga à do poema de partida", tentando, além disso, "compensar perdas" a que está sujeito um trabalho de reprodução poética que precisa lançar mão de "novos recursos ou efeitos" (TÁPIA, 2016, p. 5).

\footnotetext{
${ }^{19}$ Claro é que a morte do operário empresta um tom sombrio ao texto, mas isso não corresponde ao "obscuro" acima mencionado.
} 


\section{Referências}

BRAAK, Ivo. Poetik in Stichworten. Kiel: Verlag Ferdinand Hirt, 1980.

BRANDT, Sarita. Das Bauwerk. Chico Buarque. In: BINDER, Wolfgang/ FÄHNDRICH, Hartmut / IMFELD, Al / MERTIN, Ray-Güde / RIEMENSCHNEIDER, Dieter / RIPKEN, Peter (eds.). Betonblumen. Aus fernen Großstädten. Berlim: Fischer Taschenbuch, 1992.

CÉSAR, Ana Cristina. Crítica e tradução. 1a ed. São Paulo: Companhia das Letras, 2016.

ECO, Umberto. Dire quasi la stessa cosa. Esperienze di traduzione. Milão: Bompiani, 2013.

FABER, Heiner. Baustelle. In: BrasilienNachrichten. Osnabrück: brasilien initiative e.V., 1987.

HOUAISS, Antônio; VILLAR, Mauro de Salles. Dicionário Houaiss da Língua Portuguesa. Rio de Janeiro: Objetiva, 2001.

MACAMBIRA, José Rebouças. Estrutura Musical do Verso e da Prosa. Fortaleza: Secretaria de Cultura e Desporto, 1983.

MAGALHÃES, Marcela Ulhôa Borges. Poética e Semiótica: um estudo sobre a lírica de Chico Buarque. Estudos Linguísticos, São Paulo, 40 (3): p. 18041813, set-dez 2011.

MANGOLD, Max. DUDEN. Das Aussprachewörterbuch. Mannheim: Dudenverlag, 2005.

MENESES, Adélia Bezerra de. Desenho mágico: poesia e política em Chico Buarque. $3^{\mathrm{a}}$ ed. São Paulo: Ateliê Editorial, 2002.

NÊUMANNE, José. Ave \& Vate. In: Jornal da Tarde. Rio de Janeiro, 1/5/1999. PIRES, Martinho Vaz. Gramática da Língua Alemã. Porto: Porto editora, 1997.

ROMÃO, Tito Lívio Cruz. Composição nominal em alemão: algumas peculiaridades do modelo "adjetivo + substantivo". Revista Trama, v. 14, n. 31, p. 152-161, 2018.

SCHWAMBORN, Ingrid. Hochhausbau. In: SCHWAMBORN, Ingrid; SPERBER, Achim. Brasilien. Land der Extreme. Dortmund: Harenberg Edition, 1990.

SELANSKI, Wira. Renovos de Mitos. Rio de Janeiro: Comp Brasil. de Artes Gráficas, 1986. 
SELANSKI, Wira. Correntes da Literatura Alemã. Rio de Janeiro: Impr. Velha Lapa, 1997.

SELANSKI, Wira. As poesias de "Niedere Minne“ de Walther von der Vogelweide. Rio de Janeiro: Impressora Velha Lapa, 1997.

SELANSKI, Wira. Fonte. A Balada Alemã. Rio de Janeiro: Editora Velha Lapa, 1998.

SELANSKI, Wira. Fonte. Antologia da Lírica Alemã. Rio de Janeiro: Ed. Velha Lapa, 1999.

SEVERIANO, Jairo; HOMEM DE MELLO, Zuza. A canção no tempo. 85 anos de músicas brasileiras. Vol. 2: 1958-1985. São Paulo: Editora 34, 1998. TÁPIA, Marcelo. A nossa poesia francesa (prefácio). In: ALMEIDA, Guilherme de. Poetas de França. 5ª ed. São Paulo: Babel, s.d.

WAINER, João. Compositor viaja no tempo e desbrava capital húngara. Folha de São Paulo. Caderno Ilustrada, 3/8/2005.

\section{Sites consultados:}

http://www.chicobuarque.com.br/texto/depoimentos/depoto_hollan da1.htm

https://browse.dict.cc/portugiesischdeutsch/constru\%C3\%A7\%C3\%A3o.html

http://sites.utoronto.ca/elul/Wowk-Wira/Wira-Wowk_Choven-naobriju_Spohady.pdf

www.chicobuarque.com.br/texto/mestre.asp?pg=entrevistas/entre_19 89.htm

\section{Resumo}

O poema-canção "Construção", de Chico Buarque (1971), obteve inegável êxito na MPB. Para tradutores, revela-se complexo graças a seus versos alexandrinos e ao vocabulário bastante variado, em que se destacam polissílabos proparoxítonos no final de cada verso, que alternam sua posição dentro do texto. Reconhecendo a tarefa de tradução como recriação e 
reprodução poética, à luz de Tápia (s.d.) e César (2016), este artigo traz uma análise da recriação feita por Wira Selanski em alemão, intitulada "Bauwerk". Discutem-se as estratégias utilizadas pela tradutora e os efeitos da sua reprodução poética.

Palavras-chave: Poema; Canção; Tradução; Reprodução poética; Português; Alemão.

\begin{abstract}
The poem-song "Construção", by Chico Buarque (1971), was undeniably successful in Brazil. Here, translators must deal with a complex text, due to its alexandrine verses and a rich vocabulary; moreover, proparoxytone polysyllables appear at the end of each verse, alternating their position within the text. Recognizing the task of translation as a poetic recreation and reproduction, in the light of Tápia (s.d.) and César (2016), we analyze Wira Selanski's recreation in German, entitled "Bauwerk". Here we focus on strategies used by the translator and the effects of her poetic reproduction.
\end{abstract}

Keywords: Poem; Song; Translation; Poetic Reproduction; Portuguese; German. 